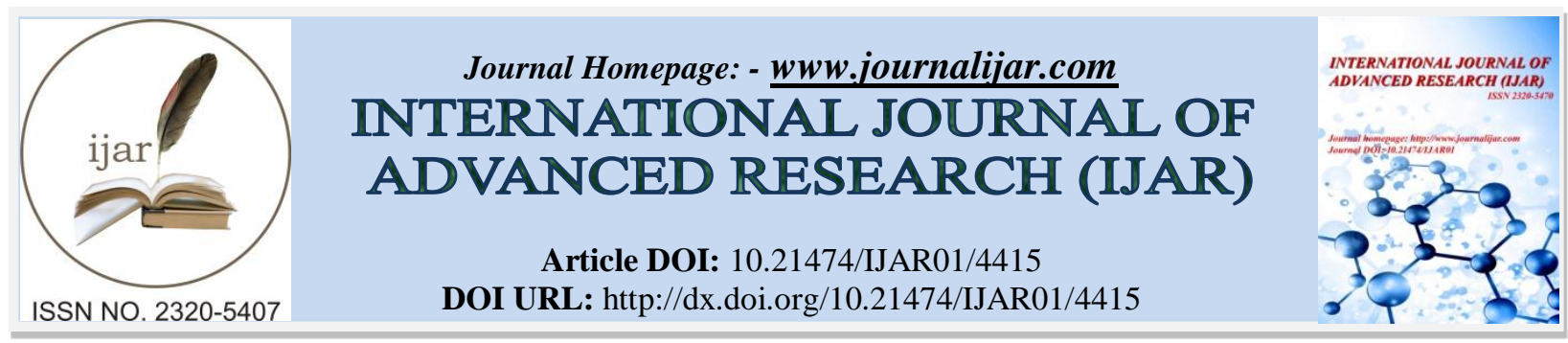

RESEARCH ARTICLE

\title{
MODELLING OF QUEUEING SYSTEM AT SALES CHECKOUT AND ANALYSIS OF CONSUMER BEHAVIOUR: AN EMPIRICAL STUDY AT A SUPERMARKET IN BENGALURU.
}

Rema.V. ${ }^{1}$, K.Sikdar ${ }^{2}$ and Dhanjit Medhi ${ }^{3}$.

1. Ramaiah Institute of Management, Bengaluru, India.

2. Department of Mathematics, BMS Institute of Technology \& Management, Bengaluru, India.

3. Ramaiah Institute of Management, Bengaluru, India.

\section{Manuscript Info}

\section{Manuscript History}

Received: 08 April 2017

Final Accepted: 10 May 2017

Published: June 2017

Key words:-

Customer purchase behaviour, Customer

loyalty, Customer Satisfaction,

Supermarket, Sales checkout, Queueing

model, Monte Carlo Simulation

\begin{abstract}
Increased competition from online grocery stores has necessitated brick and mortar retailers to understand consumers better. This research attempts to understand consumer demographics, key factors driving buying behaviour, impact of loyalty programs on customer loyalty intentions at a well-established brick and mortar supermarket. A structured questionnaire was administered to 100 shoppers at a select Supermarket in Bengaluru city. Statistical tests of chi-square and correlation have been used. Convenience and ease of access, variety of product categories, quality and availability of products have emerged as key factors driving customer purchase behaviour. There is a significant impact of store loyalty programs on customers of different age groups. Empirical data of arrival and service times during the checkout process was recorded through observation technique to analyse the performance measures of the multi-channel multi-queue system at the checkout counters. Monte Carlo Simulation technique was used to analyse the operating characteristics of queues, efficiency and server utilization. These factors play a predominant role in understanding customer satisfaction during the checkout process and help the Management to evaluate service efficiency at the checkout points.
\end{abstract}

Copy Right, IJAR, 2017,. All rights reserved.

\section{Introduction:-}

With e-grocery becoming a parlance among consumers today, it has become quintessential for retailers to create an engaging customer experience at their brick and mortar outlets. This requires understanding consumer buying behaviour, which basically is the study of how individuals and groups select, buy, use and dispose goods, services, ideas, or experiences to satisfy their needs and wants (Kotler and Keller, 2006). Owing to intense competition, it becomes all the more important for retailers to understand consumer demographics, psychographics and behavioural variables that lead to purchase intentions. With rising household incomes, consumer spending, internet penetration and customer sophistication, there is a need to understand the salient factors that drive consumers to purchase at a brick and mortar grocery retail outlet. In the era of digitalisation, speedier checkout process rank among the top trends for grocery shopping (Karolefski, 2016). For the grocery sector, the key drivers of consumer buying 
behaviour are brand image, low daily prices, changing trends (Afande et al. 2015) in addition to offers, convenience, proximity and variety. Delays and queuing issues are typical problems in our daily lives and especially at a supermarket checkout counter, this would be one of the key reasons for customer dissatisfaction. Hence a quantitative approach explaining the efficiency of the checkout process at the time of billing will provide better insights to the Management on evaluating the performance of the servers. This will help to build effective queue management techniques at the store.

Although there are many research studies on consumer behaviour, behavioural models, customer loyalty, there are no studies undertaken to explain concept of buying behaviour at supermarkets integrating customer loyalty and study of customer satisfaction derived from quantitative analysis of queueing systems during the sales checkout process.

Given the above context, the objectives of the present study are set as follows:

- To ascertain the key factors affecting customer purchase behaviour at supermarkets

- To determine the impact of store loyalty program on customers of different age groups

- To analyse the effectiveness of the queuing system by measuring its operating characteristics and its implication on customer satisfaction.

\section{Literature Review:-}

Customer buying behaviour at supermarkets and thereafter satisfaction are determined by a number of factors. Applebaum (1951), in his study with respect to customer behaviour in retail stores, analysed the various aspects that are involved in understanding the customer behaviour patterns such as place of purchase, items of purchase, time, frequency and method of purchase and also response to sales promotion techniques adopted by retail stores. The conceptual research approach adopted throws light on determinants of consumer behaviour. Sangvikar and Katole (2012) have carried out a study on consumer purchase behaviour in organized retail outlets through a structured questionnaire and interview technique. Descriptive and inferential analysis showed that price discount followed by variety of products and convenience were the key factors affecting consumer behaviour. Further it was analysed that customers spend more towards garments and cosmetics, followed by food and eatables, and electronic goods. The study revealed that, in general, shopping habits of Indian consumers were changing due to the growing disposable income. Rana et al. (2015) conducted a survey on 150 customers in Kedah and Perlis states in Malaysia to assess the factors affecting purchase intention of customers who shop at Hypermarkets. Among the various factors considered in the study, such as product quality, brand image, socioeconomic condition and social influence; statistical analysis revealed that brand image had the highest impact on purchase intention of customers, followed by the quality of products.

Wang, Wen-Cheng et al. (2009) conducted a study in the context of Chinese retail supermarket through a survey approach. The researchers used factor analysis to identify the determinants of service loyalty. Zakaria et al. (2014) investigated the relationship between loyalty program, customer satisfaction and customer loyalty with reference to a study conducted in a supermarket at Kuala Lumpur based on purposive sampling technique. A correlation analysis used by the researchers revealed that there exist positive and significant relationship among loyalty program, customer satisfaction and customer loyalty. A study conducted by Afande et al. (2015) on factors affecting customer loyalty at Supermarkets in Nyeri Town, Kenya using descriptive research methods reveal that price, changing customer preferences and brand image are among the top reasons for customer loyalty. Neupane (2015), in the context of retail supermarket chain in UK studied the inter-relationship between brand image, customer satisfaction and loyalty intention of customers. Data was collected from 120 customers; statistical techniques like correlation and regression were employed. The results indicated significant relationship between the above stated variables.

Waiting in queues is a phenomenon which continues to be common in congested, urbanized, high-tech societies. While customers do not like these waits, the Management of the establishments also do not like the customers to wait, since it may cost them business when customers are dissatisfied with long waiting lines. (Gross et al. (2014)). Among the significant factors affecting customer satisfaction and loyalty is the time taken for the customer to checkout at supermarkets. Managing the queues generated in the supermarkets and reducing the customer waiting time has been a challenge. Chinwuko et al. (2014) conducted a study on the queues developed at a bank in Nigeria. A quantitative research approach was used and data was collected for over a week. An analytical approach was used to assess the operating characteristics of the queueing system. Results showed that the bank had to increase the number of servers to cater to the customer requirement. Igwe et al. (2014) have analysed a single-server queueing 
system by collecting data through observation from select supermarkets. The focus was on analytical method of analysis of queues at select supermarkets in Makurdi Town, Nigeria. Results revealed that mean service rate was poor and the average time a customer spent while waiting for service was too long. Suggestions were made towards improving service facilities. S. Shanmugasundaram and S. Punitha (2014) in their study on multi-server queueing systems analysed the multi-channel queueing framework through a simulation approach. Patient arrival and service time data was collected from a hospital. The authors analysed the expected queue length at each server and attempted to use the simulation model in a healthcare setting. An analysis of sales checkout process at Alankulama Supermarket, Srilanka was carried out by Priyangika and Cooray (2016). The authors used a questionnaire approach to analyse performance measures of queueing system at the billing counter and measured utilization, waiting time, queue length by adopting a simulation approach. The study provides insights on resource planning in terms of number of servers required during the checkout process.

This paper integrates analysis of dimensions of buying behaviour, loyalty and satisfaction of customers at a popular supermarket. The research analyses the purchase behaviour of customers through aspects of frequency of purchase and categories of products purchased. The key drivers of buying behaviour are analysed. The relationship between store loyalty programs and loyalty intentions of customers among different age groups is established. An assessment of customer satisfaction is made through empirical observation and analysis of waiting lines at the checkout counter using a queueing simulation approach. Through assessment of the above stated dimensions, this paper will provide better insights to understand the overall shopper's behaviour and satisfaction at supermarkets.

\section{Research Methodology:-}

Owing to variety of products and variety in modes of shopping, consumers today have become very demanding. This study attempts to assess the key factors affecting consumer purchase behaviour at Supermarkets. Consumers are hitting multiple retail outlets to shop for grocery, challenging the very concept of 'customer loyalty.' Through this study, the relationship between the store loyalty programs on customers of different age groups is analysed.

The current study adopts a descriptive research design. The main purpose of descriptive research is to describe characteristics of a population or a phenomenon under study (Zikmund, 2000). This study describes the various characteristics that drive individuals' buying behaviour at Supermarkets. A well-known established Supermarket in one of the busy areas of Bengaluru city in Karnataka state in India with high footfalls was considered to collect data. A structured questionnaire was administered to 100 customers who visited the considered Supermarket outlet. The sampling design used was purposive sampling. Stratification was also adopted where 'age group' was the basis of classification. The questionnaire consisted of two sections-firstly, based on the demographics to understand the holistic customer profile followed by specific study questions to achieve the stated research objectives. The questionnaire was a blend of different types of questions including dichotomous, multiple choice, open ended and Likert-scale questions. Questionnaire was used to collect data with respect to understanding the buying behaviour and the impact of store loyalty program on customers of different age groups. While the questionnaire was largely self-administered, for a few respondents the authors played the role of enumerators and recorded responses.

A detailed analysis was carried out using MS EXCEL and SPSS and the key findings are presented as graphs. Along with graphical representation, the following two hypotheses sets were developed and tested related to key attributes affecting buying behaviour and impact of loyalty program on customers. The statements of the null hypotheses are presented below.

\section{Hypothesis Set 1:-}

$H_{01}$ : Customer purchase behaviour is independent of 'convenience and ease of access' as a key factor.

$\mathrm{H}_{02}$ : Customer purchase behaviour is independent of 'availability of variety of brands of a particular product' as a key factor.

$H_{03}$ : Customer purchase behaviour is independent of 'store ambience' as a key factor.

\section{Hypothesis Set 2:-}

$H_{o 4}$ : There is no significant impact of store loyalty program on customers of different age groups.

Hypotheses set 1 were tested using Chi-square test for independence of attributes to identify the key factors affecting consumer buying behaviour at a Supermarket. Chi-square test may be used to test the independence of two 
attributes, thereby testing their association. (Chawla et al. (2014)). Hypothesis set 2 was tested using Correlation test of significance.

Customer satisfaction that results from shopping at a particular Supermarket may be attributed to several factors like shopping experience, proximity, variety of products available etc. In addition, one of the key drivers of customer satisfaction may be associated with waiting time at the checkout counters. Delays at the billing or checkout points are of common occurrence in supermarkets which could prevent the customer from coming back to the store. With an objective to model the checkout process, primary data was collected using Observation technique. The observation process began at 4:00 PM on a weekday for two hours. Parameters such as the arrival time of the customer in the queue, service time, number of customers in queue etc. were observed and recorded. The store had two servers and two parallel queues (Fig.4). A multi-channel, multi-queuing system was analysed through Monte Carlo simulation technique. The purpose was to understand the different performance measures or indicators to enable the supermarket develop efficient queue management techniques.

\section{Analysis:-}

Data analysis is outlined into three sections-the first section analyses respondent demographics and factors affecting purchase behaviour at the supermarket using descriptive and inferential statistical techniques. The second section presents analysis of store loyalty program and its impact on customers of different age groups using descriptive and inferential statistical techniques. The third section analyses the waiting lines at the checkout counters and measures the efficiency of the servers using an operations research 'simulation' approach.

\section{Section I:-}

This section presents analysis of respondent demographics, aspects of respondent buying behaviour at the Supermarket and key factors affecting the buying behaviour. Table 1 shows analysis of demographic profile of the sample group of respondents.

Table 1:- Respondent Demographic profile.

\begin{tabular}{|c|c|c|}
\hline Sl.No. & Demographic profile & Percentage (in \%) \\
\hline 1 & \multicolumn{2}{|c|}{ AGE } \\
\hline & $18-25$ & 30 \\
\hline & $26-33$ & 40 \\
\hline & $34-41$ & 25 \\
\hline & $42-49$ & 5 \\
\hline 2 & \multicolumn{2}{|c|}{ GENDER } \\
\hline & Male & 52 \\
\hline & Female & 48 \\
\hline 3 & \multicolumn{2}{|c|}{ MONTHLY INCOME (in Rs.) } \\
\hline & Below 10,000 & 28 \\
\hline & $10,001-20,000$ & 10 \\
\hline & $20,001-30,000$ & 12 \\
\hline & $30,001-40,000$ & 30 \\
\hline & $40,001-50,000$ & 10 \\
\hline & Above 50,000 & 10 \\
\hline \multirow[t]{5}{*}{4} & \multicolumn{2}{|c|}{ MEMBERS IN THE FAMILY } \\
\hline & $1-2$ & 4 \\
\hline & $3-4$ & 65 \\
\hline & $5-6$ & 25 \\
\hline & 7 and more & 6 \\
\hline
\end{tabular}

Table 2 presents an overview of respondents' behaviour with respect to visit to the store. It can be inferred that maximum number of respondents travel a distance of one to four kilometers to reach this store, visiting the store as frequently as once in three days or at least once a week. 
Table 2:- Distance travelled to visit the store and frequency of visit to the store

\begin{tabular}{|c|c|c|c|}
\hline $\begin{array}{c}\text { Distance travelled to } \\
\text { visit the store }\end{array}$ & $\begin{array}{c}\text { Percentage } \\
\text { (in \%) }\end{array}$ & Frequency of visit to the store & $\begin{array}{c}\text { Percentage } \\
\text { (in \%) }\end{array}$ \\
\hline Less than $1 \mathrm{~km}$ & 19 & Daily & 5 \\
\hline $1 \mathrm{~km}-2 \mathrm{~km}$ & 43 & Once in three days & 33 \\
\hline $3 \mathrm{~km}-4 \mathrm{~km}$ & 29 & Weekly & 36 \\
\hline More than $4 \mathrm{~km}$ & 9 & Once in two weeks & 10 \\
\hline & & Monthly & 16 \\
\hline
\end{tabular}

Figure 1 presents an overview of categories of products purchased at the supermarket. Consumers largely visit this store to buy grocery and staples, followed by cosmetics, fruits and vegetables and dairy products.

Fig 1:- Categories of products purchased

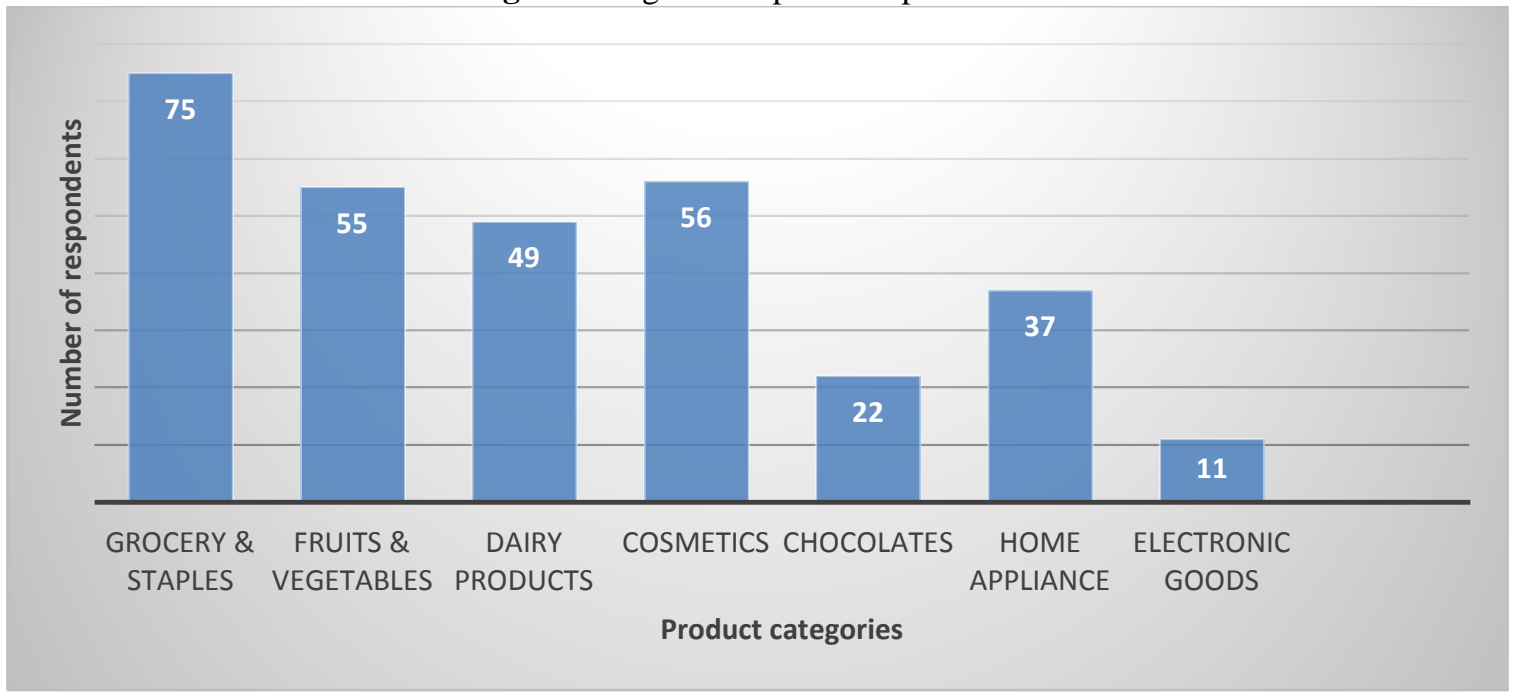

Figure 2 is obtained on analysing the key factors affecting customer purchase behaviour at the Supermarket based on a five-point agree-disagree Likert scale. It can be inferred that $76 \%$ purchase at the store because of convenience and ease of access, $67 \%$ are of the opinion that the store offers variety of product categories and about $50 \%$ purchase at the store since it offers variety of brands of a particular product. About $54 \%$ purchase at the store because of the quality of the products. $43.0 \%$ respondents agree that they purchase because of the discounts and offers at the store. A very small percentage $(22.0 \%)$ feels that the store has a customer friendly return policy. 53\% of shoppers at the store purchase there due to availability of products, $47 \%$ purchase at the store due to its ambience which includes modern equipment and fixtures, visually appealing set up including catalogues and shopping bags. 
Fig. 2:- Key factors affecting customer purchase at the store

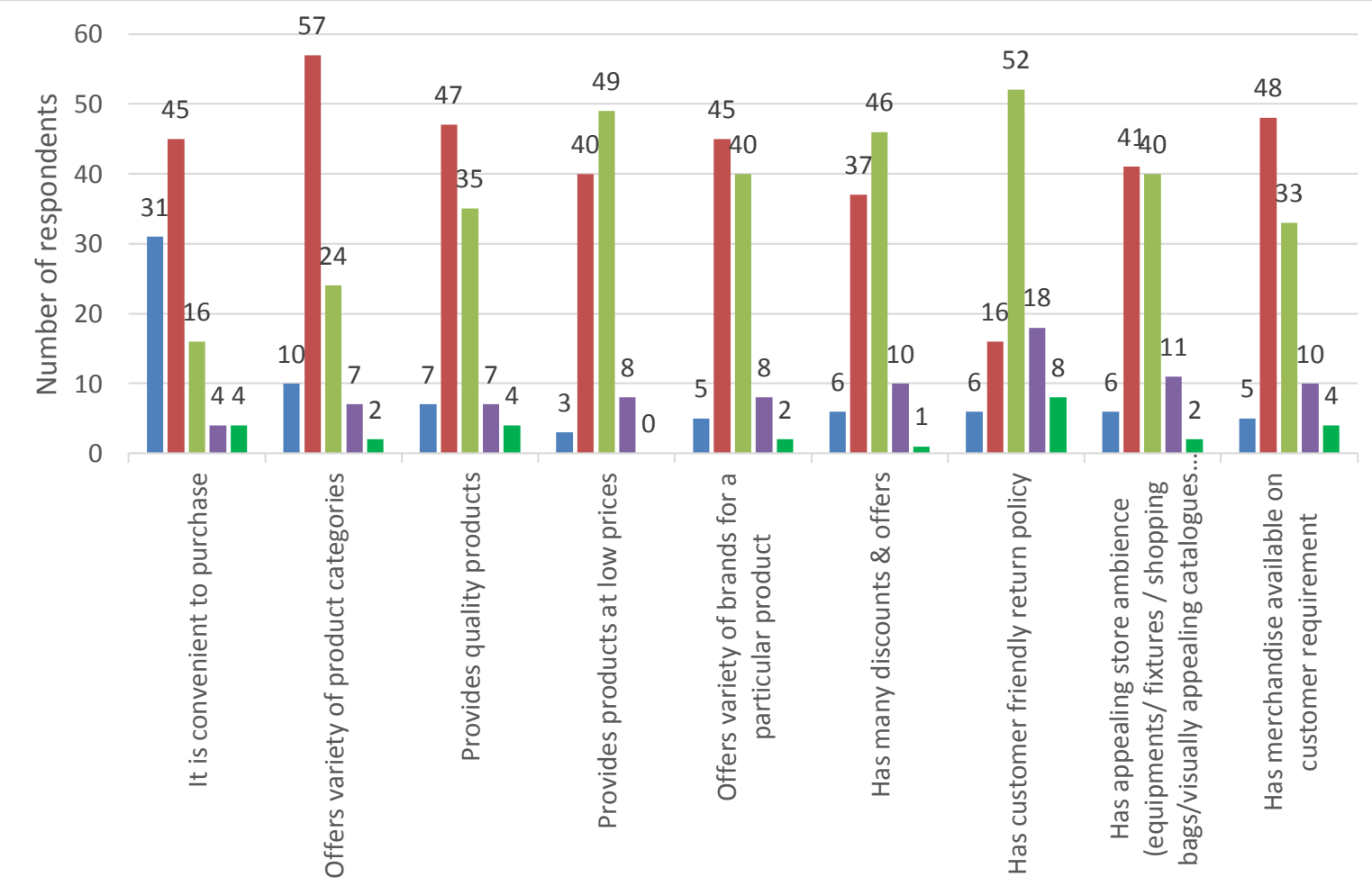

Reasons

- Strongly Agree $\quad$ Agree $\quad$ Neither Agree Not Disagree $\quad$ Disagree $\quad$ Strongly Disagree

Table 3:- Summary of Statistical analysis using Chi-square test: the test for association/independence of attributes.

\begin{tabular}{|c|l|c|c|}
\hline Sl.No. & \multicolumn{1}{|c|}{ Null Hypotheses } & \multicolumn{1}{|c|}{-value } & \multicolumn{1}{|c|}{ Decision } \\
\hline 1. & $\begin{array}{l}\text { Customer purchase behaviour is independent of 'convenience and ease } \\
\text { of access' as a key factor }\end{array}$ & 0.011 & Reject the null \\
\hline 2. & $\begin{array}{l}\text { Customer purchase behaviour is independent of 'availability of variety } \\
\text { of brands of a particular product' as a key factor }\end{array}$ & 0.298 & $\begin{array}{l}\text { Fail to reject } \\
\text { the null }\end{array}$ \\
\hline 3. & $\begin{array}{l}\text { Customer purchase behaviour is independent of 'store ambience' as a } \\
\text { key factor }\end{array}$ & $\begin{array}{l}\text { Fail to reject } \\
\text { the null }\end{array}$ \\
\hline
\end{tabular}

The null hypothesis is rejected for a ' $p$-value' less than the level of significance (0.05). Chi-square tests for independence of attributes were performed with respect to select characteristics to identify the key factors affecting customer purchase behaviour at the Store. The analysis consolidated in Table 3 reveals that the result is significant for the 'convenience and ease of access' attribute and insignificant with respect to 'availability of variety of brands' and 'store ambience.'

\section{Section II:-}

This paper also studies the impact of loyalty programs of the supermarket on customers of different age groups. The types of benefits of loyalty programs availed by customers is analysed in the pie chart (Figure 3) below. 28\% of the respondents have availed the benefits of loyalty card through redemption of loyalty points and $24 \%$ of them have used the special discounts offered on loyalty cards while $22 \%$ have not used loyalty cards at all. 
Fig. 3:- Benefits availed using loyalty cards.

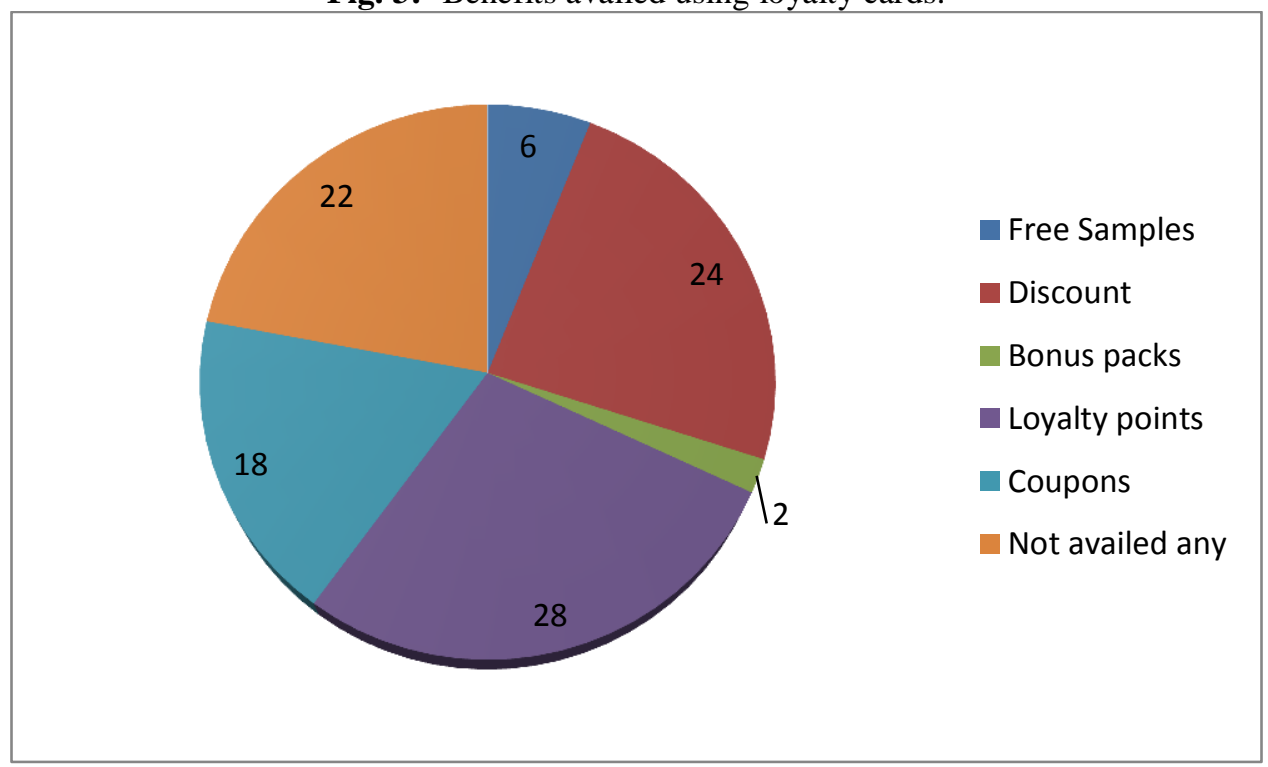

A hypothesis with respect to the impact of loyalty programs on individuals of different age groups was tested using SPSS. Spearman's correlation test of significance was used to test the below mentioned hypothesis. $\mathrm{H}_{\mathrm{o}}$ : There is no significant impact of store loyalty program on customers of different age groups. $\mathrm{H}_{1}$ : There is a significant impact of store loyalty program on customers of different age groups.

Table 4:- Correlation Analysis output:-

Correlations

\begin{tabular}{|lll|r|r|}
\hline & & \multicolumn{1}{|c|}{$\begin{array}{c}\text { Age group of } \\
\text { customers }\end{array}$} & $\begin{array}{c}\text { Impact of } \\
\text { loyalty } \\
\text { program }\end{array}$ \\
\hline Spearman's tho & Age group of customers & Correlation Coefficient & 1.000 & $.225^{*}$ \\
& & Sig. (2-tailed) &. & .024 \\
& $\mathrm{~N}$ & 100 & 100 \\
\cline { 2 - 5 } & Impact of loyalty program & Correlation Coefficient & $.225^{*}$ & 1.000 \\
& Sig. (2-tailed) & .024 &. \\
& $\mathrm{~N}$ & 100 & 100 \\
\hline
\end{tabular}

*. Correlation is significant at the 0.05 level (2-tailed).

Analysis reveals that the result is significant. With $p$-value 0.024 at $5 \%$ level of significance $(\alpha)$, the null hypothesis is rejected. Hence it can be concluded that there is a significant impact of store loyalty program on customers of different age groups.

\section{Section III:-}

This section presents analysis of multi-server multi-queue model at the checkout counter of the Supermarket. Monte Carlo simulation technique is used to analyse the operating characteristics of queues, efficiency and server utilization. These factors play a significant role in understanding customer satisfaction at the store with respect to checkout process.

A queueing system can be described as customers arriving for service, waiting for the service if it is not immediate, and if having waited for service, leaving the system after being served (Gross et al. (2014)). In the present study, the queueing system is described by arrival of customers at two checkout/billing counters in the supermarket, waiting in the queues, being served at one of the two counters and then leaving the Supermarket, as shown in the conceptual framework below (Figure 4). 
Fig. 4:- Conceptual framework of the Queueing process at the Checkout Counter of the Supermarket

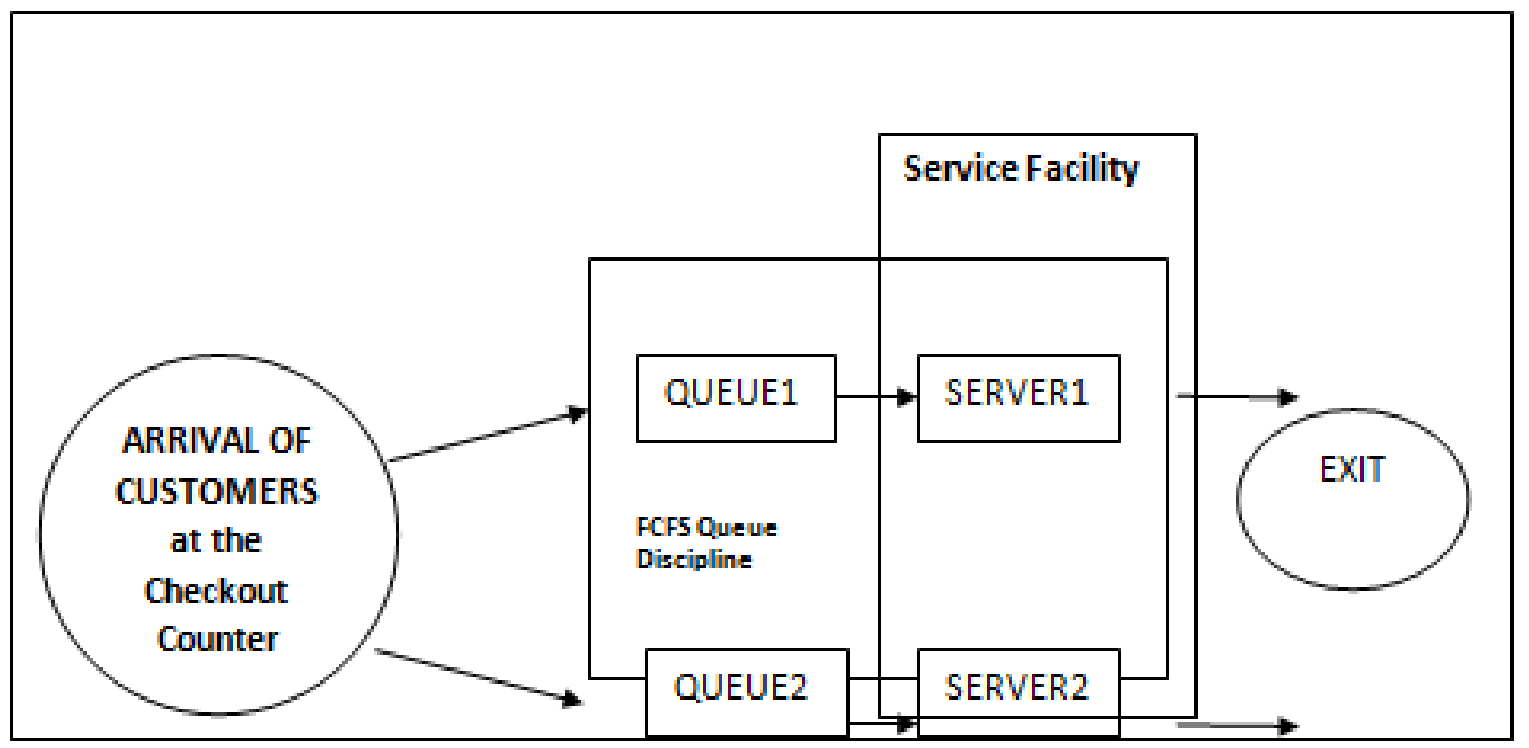

Description of Queueing system: There are four basic characteristics of queueing process that describe a queueing system ((Gross et al. (2014)).

1. Arrival pattern: A customer's arrival at the store and at the checkout/ billing counter is a random/stochastic phenomenon. The arrival times of customers are recorded through an observation technique and the time between successive arrivals (inter-arrival times) is computed. The arrival rate ' $\lambda$ ' which indicates the number of customers arriving at the checkout counter per unit time (per minute) is computed.

2. Service pattern: The service process is governed by the service rate ' $\mu$ ', which indicates the number of customers served per unit time (per minute).

3. Number of service channels: The supermarket has two servers at two checkout counters serving the arriving customers. Hence this is a case of multi-server queueing system, fed by two queues, one for each server.

4. Queue Discipline: Queue discipline refers to the manner in which customers in queue are selected for service. The queue discipline here is first come, first served (FCFS).

Observation data was collected from the store where the observation process was carried out on a weekday 4:00PM onwards for two hours. The arrival time, service time, number of customers in queue and departure time were observed and recorded for the two queues generated at the two servers in the checkout unit. Data was recorded for 21 customers at each of the two queues. Random number generation technique using EXCEL's RAND function (Albright et al. (2014)) was used to generate random numbers to simulate trials up to 50. The Monte Carlo simulation technique uses the concept of random numbers.

Based on the observation data collected with respect to arrival times, inter-arrival times were computed. For the first channel (server), computations of the inter-arrival time probability distribution, service time distribution, waiting time distribution and detailed Monte Carlo Simulation using random number generation is shown from tables 5 to 8 . Similar computations for the second channel (server) are shown in detail from tables 9 to 12. Random number generator was used to simulate the trials based on the probability distribution for inter-arrival times, service times and waiting times. Key operating characteristics i.e. arrival rate, service rate, average waiting time for a customer in the queue and in the system (i.e. time spent in the queue and at service) and service facility utilization (percentage of the time the servers are busy) are computed for each of the two queues. An average measure of operating characteristics has been computed based on the results. 
Table 5:- Customer Inter-arrival time probability distribution for queue one (at the first server).

\begin{tabular}{|c|c|c|c|c|c|}
\hline $\begin{array}{c}\text { Inter-arrival time (in } \\
\text { minutes) }\end{array}$ & Frequency & $\begin{array}{c}\text { Cumulative } \\
\text { Frequency }\end{array}$ & Probability & $\begin{array}{c}\text { Cumulative } \\
\text { Probability }\end{array}$ & $\begin{array}{c}\text { Random } \\
\text { number interval }\end{array}$ \\
\hline 0 & 2 & 2 & 0.10 & 0.10 & $00--09$ \\
\hline 1 & 1 & 3 & 0.04 & 0.14 & $10--13$ \\
\hline 2 & 3 & 6 & 0.14 & 0.28 & $14--27$ \\
\hline 3 & 1 & 7 & 0.04 & 0.32 & $28--31$ \\
\hline 4 & 2 & 9 & 0.10 & 0.42 & $32--41$ \\
\hline 6 & 2 & 11 & 0.10 & 0.52 & $42--51$ \\
\hline 7 & 6 & 17 & 0.29 & 0.81 & $52--80$ \\
\hline 8 & 1 & 18 & 0.04 & 0.85 & $81--84$ \\
\hline 10 & 1 & 19 & 0.04 & 0.89 & $85--88$ \\
\hline 11 & 2 & 21 & 0.10 & $0.99 \sim 1$ & $89--98$ \\
\hline
\end{tabular}

Table 6:- Service time distribution for server one

\begin{tabular}{|c|c|c|c|c|c|}
\hline $\begin{array}{c}\text { Service time (in } \\
\text { minutes) }\end{array}$ & Frequency & $\begin{array}{c}\text { Cumulative } \\
\text { Frequency }\end{array}$ & Probability & $\begin{array}{c}\text { Cumulative } \\
\text { Probability }\end{array}$ & $\begin{array}{c}\text { Random number } \\
\text { interval }\end{array}$ \\
\hline 2 & 3 & 3 & 0.14 & 0.14 & $00-13$ \\
\hline 3 & 8 & 11 & 0.38 & 0.52 & $14-51$ \\
\hline 4 & 2 & 13 & 0.10 & 0.62 & $52-61$ \\
\hline 5 & 1 & 14 & 0.04 & 0.66 & $62-65$ \\
\hline 6 & 2 & 16 & 0.10 & 0.76 & $66-75$ \\
\hline 7 & 2 & 18 & 0.10 & 0.86 & $76-85$ \\
\hline 8 & 2 & 20 & 0.10 & 0.96 & $86-95$ \\
\hline 9 & 1 & 21 & 0.04 & 1.00 & $96-99$ \\
\hline Total & $\mathbf{2 1}$ & & & & \\
\hline
\end{tabular}

Table 7:- Customer waiting time distribution for server one.

\begin{tabular}{|c|c|c|c|c|c|}
\hline $\begin{array}{c}\text { Waiting time (in } \\
\text { minutes) }\end{array}$ & Frequency & $\begin{array}{c}\text { Cumulative } \\
\text { Frequency }\end{array}$ & Probability & $\begin{array}{c}\text { Cumulative } \\
\text { Probability }\end{array}$ & $\begin{array}{c}\text { Random number } \\
\text { interval }\end{array}$ \\
\hline 0 & 5 & 5 & 0.24 & 0.24 & $00--23$ \\
\hline 1 & 4 & 9 & 0.19 & 0.43 & $24--42$ \\
\hline 2 & 1 & 10 & 0.04 & 0.47 & $43--46$ \\
\hline 3 & 3 & 13 & 0.14 & 0.61 & $47--60$ \\
\hline 4 & 3 & 16 & 0.14 & 0.75 & $75--74$ \\
\hline 8 & 1 & 17 & 0.04 & 0.79 & $79--82$ \\
\hline 9 & 1 & 18 & 0.04 & 0.83 & $83--92$ \\
\hline 10 & 2 & 20 & 0.10 & 0.93 & $93-96$ \\
\hline 12 & 1 & 21 & 0.04 & 0.97 & \\
\hline
\end{tabular}

Table 8:- Detailed simulation of the queuing process for server one.

\begin{tabular}{|c|c|c|c|c|c|c|c|}
\hline Trial & $\begin{array}{c}\text { Random } \\
\text { Number } \\
\text { (Arrival } \\
\text { Time) }\end{array}$ & $\begin{array}{c}\text { Inter- } \\
\text { arrival time }\end{array}$ & $\begin{array}{c}\text { Random } \\
\text { Number } \\
\text { (Service } \\
\text { Time) }\end{array}$ & $\begin{array}{c}\text { Service } \\
\text { Time(min) }\end{array}$ & $\begin{array}{c}\text { Arrival } \\
\text { Time }\end{array}$ & $\begin{array}{c}\text { Random } \\
\text { Number } \\
\text { (Customer } \\
\text { waiting time) }\end{array}$ & $\begin{array}{c}\text { Customer } \\
\text { Waiting } \\
\text { time }\end{array}$ \\
\hline 1 & - & 0 & - & 3 & $04: 05$ & - & 1 \\
\hline 2 & - & 6 & - & 8 & $04: 11$ & - & 1 \\
\hline 3 & - & 6 & - & 3 & $04: 17$ & - & 3 \\
\hline 4 & - & 2 & - & 7 & $04: 19$ & - & 4 \\
\hline 5 & - & 7 & - & 6 & $04: 26$ & - & 4 \\
\hline 6 & - & 11 & - & 3 & $04: 37$ & - & 0 \\
\hline
\end{tabular}




\begin{tabular}{|c|c|c|c|c|c|c|c|}
\hline 7 & - & 1 & - & 9 & $04: 38$ & - & 2 \\
\hline 8 & - & 2 & - & 6 & 04:40 & - & 9 \\
\hline 9 & - & 3 & - & 8 & $04: 43$ & - & 12 \\
\hline 10 & - & 10 & - & 7 & 04:53 & - & 10 \\
\hline 11 & - & 7 & - & 3 & 05:00 & - & 10 \\
\hline 12 & - & 11 & - & 5 & 05:11 & - & 3 \\
\hline 13 & - & 0 & - & 4 & 05:11 & - & 8 \\
\hline 14 & - & 8 & - & 3 & 05:19 & - & 4 \\
\hline 15 & - & 4 & - & 2 & $05: 23$ & - & 3 \\
\hline 16 & - & 4 & - & 3 & $05: 27$ & - & 1 \\
\hline 17 & - & 7 & - & 3 & $05: 34$ & - & 0 \\
\hline 18 & - & 2 & - & 4 & $05: 36$ & - & 1 \\
\hline 19 & - & 7 & - & 2 & $05: 43$ & - & 0 \\
\hline 20 & - & 7 & - & 2 & $05: 50$ & - & 0 \\
\hline 21 & - & 7 & - & 3 & $05: 57$ & - & 0 \\
\hline 22 & 59 & 7 & 76 & 7 & 06:03 & 48 & 3 \\
\hline 23 & 58 & 7 & 15 & 3 & 06:10 & 0 & 0 \\
\hline 24 & 82 & 8 & 42 & 3 & $06: 18$ & 30 & 1 \\
\hline 25 & 31 & 3 & 97 & 9 & $06: 21$ & 74 & 4 \\
\hline 26 & 23 & 2 & 65 & 5 & $06: 23$ & 59 & 3 \\
\hline 27 & 14 & 2 & 44 & 3 & $06: 25$ & 2 & 0 \\
\hline 28 & 9 & 0 & 57 & 4 & $06: 25$ & 54 & 3 \\
\hline 29 & 91 & 11 & 36 & 3 & $06: 36$ & 42 & 1 \\
\hline 30 & 9 & 0 & 31 & 3 & $06: 36$ & 70 & 4 \\
\hline 31 & 26 & 2 & 65 & 5 & $06: 38$ & 74 & 4 \\
\hline 32 & 75 & 7 & 41 & 3 & $06: 45$ & 43 & 2 \\
\hline 33 & 48 & 6 & 71 & 6 & $06: 51$ & 41 & 1 \\
\hline 34 & 31 & 3 & 1 & 2 & $06: 54$ & 46 & 2 \\
\hline 35 & 21 & 2 & 46 & 3 & $06: 56$ & 62 & 4 \\
\hline 36 & 10 & 1 & 94 & 8 & $06: 57$ & 68 & 4 \\
\hline 37 & 40 & 4 & 23 & 3 & 07:01 & 73 & 4 \\
\hline 38 & 83 & 8 & 41 & 3 & 07:09 & 9 & 0 \\
\hline 39 & 73 & 7 & 3 & 2 & $07: 16$ & 41 & 1 \\
\hline 40 & 3 & 0 & 11 & 2 & $07: 16$ & 20 & 0 \\
\hline 41 & 1 & 0 & 61 & 4 & $07: 16$ & 30 & 1 \\
\hline 42 & 73 & 7 & 84 & 7 & $07: 23$ & 54 & 3 \\
\hline 43 & 78 & 7 & 42 & 3 & $07: 30$ & 65 & 4 \\
\hline 44 & 17 & 2 & 17 & 3 & $07: 32$ & 82 & 9 \\
\hline 45 & 15 & 2 & 93 & 8 & $07: 34$ & 13 & 0 \\
\hline 46 & 84 & 8 & 58 & 4 & $07: 42$ & 95 & 12 \\
\hline 47 & 21 & 2 & 80 & 7 & $07: 44$ & 4 & 0 \\
\hline 48 & 41 & 4 & 38 & 3 & $07: 48$ & 55 & 3 \\
\hline 49 & 39 & 4 & 41 & 3 & $07: 52$ & 51 & 3 \\
\hline 50 & 71 & 7 & 71 & 6 & $07: 59$ & 40 & 1 \\
\hline
\end{tabular}

Computation of Operating Characteristics of Queue One:

- Mean inter-arrival time $=\frac{\text { Total inter-arrival time }}{\text { Total no.of arrivals }}=\frac{235}{50}$

$$
=4.7 \text { minutes per customer }
$$

- $\quad$ Arrival rate $\lambda_{1}=\frac{1}{\text { Mean inter-arrival time }}=\frac{1}{4.7}$

$$
=0.213 \text { customers per minute }
$$

- $\quad$ Mean service time $=\frac{\text { Total service time }}{\text { No.of customers served }}=\frac{219}{50}$

$=4.38$ minutes per customer 
- $\quad$ Service rate $\mu_{1}=\frac{1}{\text { Mean Service time }}=\frac{1}{4.38}$ $=0.228$ customers per minute

- Mean waiting time of customers in queue $=\frac{\text { Sum of customers waiting time }}{\text { Total no.of arrivals }}=\frac{153}{50}$ = 3.06 minutes per customer

- Mean time a customer spends in the system (checkout counter)

$=$ Average service time + Average waiting time in queue

$$
=4.38+3.06=7.44 \text { minutes }
$$

- Service facility Utilization at server one $=\frac{\lambda}{\mu}=\mathbf{0 . 9 3 4}$

Table 9:- Customer Inter-arrival time probability distribution for queue two (at the second server)

\begin{tabular}{|c|c|c|c|c|c|}
\hline $\begin{array}{c}\text { Inter-arrival time (in } \\
\text { minutes) }\end{array}$ & Frequency & $\begin{array}{c}\text { Cumulative } \\
\text { Frequency }\end{array}$ & Probability & $\begin{array}{c}\text { Cumulative } \\
\text { Probability }\end{array}$ & $\begin{array}{c}\text { Random } \\
\text { number } \\
\text { interval }\end{array}$ \\
\hline 0 & 2 & 2 & 0.10 & 0.10 & $00--09$ \\
\hline 1 & 4 & 6 & 0.19 & 0.29 & $10--28$ \\
\hline 2 & 3 & 9 & 0.14 & 0.43 & $29--42$ \\
\hline 5 & 2 & 11 & 0.10 & 0.53 & $43--52$ \\
\hline 6 & 2 & 13 & 0.10 & 0.63 & $53--62$ \\
\hline 7 & 2 & 15 & 0.10 & 0.73 & $63--72$ \\
\hline 8 & 2 & 17 & 0.10 & 0.83 & $73--82$ \\
\hline 9 & 1 & 18 & 0.04 & 0.87 & $83--86$ \\
\hline 11 & 1 & 19 & 0.04 & 0.91 & $87--90$ \\
\hline 13 & 1 & 20 & 0.04 & 0.95 & $91--94$ \\
\hline 20 & 1 & 21 & 0.04 & $0.99 \sim 1$ & $95--99$ \\
\hline Total & $\mathbf{2 1}$ & & & & \\
\hline
\end{tabular}

Table 10:- Service time distribution for server two

\begin{tabular}{|c|c|c|c|c|c|}
\hline $\begin{array}{c}\text { Service time (in } \\
\text { minutes) }\end{array}$ & Frequency & $\begin{array}{c}\text { Cumulative } \\
\text { Frequency }\end{array}$ & Probability & $\begin{array}{c}\text { Cumulative } \\
\text { Probability }\end{array}$ & $\begin{array}{c}\text { Random number } \\
\text { interval }\end{array}$ \\
\hline 1 & 3 & 3 & 0.14 & 0.14 & $00--13$ \\
\hline 2 & 8 & 11 & 0.38 & 0.52 & $14--51$ \\
\hline 3 & 7 & 18 & 0.33 & 0.85 & $52--84$ \\
\hline 4 & 1 & 19 & 0.05 & 0.90 & $85--89$ \\
\hline 5 & 1 & 20 & 0.05 & 0.95 & $90--94$ \\
\hline 7 & 1 & 21 & 0.05 & 1.00 & $95--99$ \\
\hline Total & $\mathbf{2 1}$ & & 1.00 & & \\
\hline
\end{tabular}

Table 11:- Customer waiting time distribution for server two

\begin{tabular}{|c|c|c|c|c|c|}
\hline $\begin{array}{c}\text { Waiting time (in } \\
\text { minutes) }\end{array}$ & Frequency & $\begin{array}{c}\text { Cumulative } \\
\text { Frequency }\end{array}$ & Probability & $\begin{array}{c}\text { Cumulative } \\
\text { Probability }\end{array}$ & $\begin{array}{c}\text { Random number } \\
\text { interval }\end{array}$ \\
\hline 0 & 12 & 12 & 0.57 & 0.57 & $00--56$ \\
\hline 1 & 4 & 16 & 0.19 & 0.76 & $57--75$ \\
\hline 2 & 2 & 18 & 0.10 & 0.86 & $76--85$ \\
\hline 3 & 2 & 20 & 0.10 & 0.96 & $86--95$ \\
\hline 5 & 1 & 21 & 0.04 & 1.00 & $96--99$ \\
\hline Total & $\mathbf{2 1}$ & & & & \\
\hline
\end{tabular}

Table 12: Detailed simulation of the queuing process for server two

\begin{tabular}{|c|c|c|c|c|c|c|c|}
\hline Trial & $\begin{array}{c}\text { Random } \\
\text { Number } \\
\text { (Arrival } \\
\text { Time) }\end{array}$ & $\begin{array}{c}\text { Inter-arrival } \\
\text { time }\end{array}$ & $\begin{array}{c}\text { Random } \\
\text { Number } \\
\text { (Service } \\
\text { Time) }\end{array}$ & $\begin{array}{c}\text { Service } \\
\text { Time(min) }\end{array}$ & $\begin{array}{c}\text { Arrival } \\
\text { Time }\end{array}$ & $\begin{array}{c}\text { Random } \\
\text { Number } \\
\text { (Customer } \\
\text { waiting time) }\end{array}$ & $\begin{array}{c}\text { Customer } \\
\text { Waiting } \\
\text { time }\end{array}$ \\
\hline 1 & - & 0 & - & 7 & $04: 03$ & - & 0 \\
\hline
\end{tabular}




\begin{tabular}{|c|c|c|c|c|c|c|c|}
\hline 2 & - & 6 & - & 2 & 04:09 & - & 1 \\
\hline 3 & - & 7 & - & 4 & $04: 16$ & - & 0 \\
\hline 4 & - & 1 & - & 2 & $04: 17$ & - & 3 \\
\hline 5 & - & 2 & - & 3 & $04: 19$ & - & 3 \\
\hline 6 & - & 13 & - & 2 & $04: 32$ & - & 0 \\
\hline 7 & - & 5 & - & 1 & $04: 37$ & - & 0 \\
\hline 8 & - & 1 & - & 3 & $04: 38$ & - & 0 \\
\hline 9 & - & 8 & - & 3 & $04: 46$ & - & 1 \\
\hline 10 & - & 2 & - & 5 & $04: 48$ & - & 1 \\
\hline 11 & - & 1 & - & 3 & $04: 49$ & - & 5 \\
\hline 12 & - & 20 & - & 2 & 05:09 & - & 0 \\
\hline 13 & - & 9 & - & 1 & $05: 18$ & - & 0 \\
\hline 14 & - & 8 & - & 2 & $05: 26$ & - & 0 \\
\hline 15 & - & 0 & - & 3 & $05: 26$ & - & 2 \\
\hline 16 & - & 7 & - & 2 & $05: 33$ & - & 0 \\
\hline 17 & - & 1 & - & 3 & $05: 34$ & - & 2 \\
\hline 18 & - & 6 & - & 2 & $05: 40$ & - & 0 \\
\hline 19 & - & 11 & - & 3 & $05: 51$ & - & 0 \\
\hline 20 & - & 2 & - & 2 & $05: 53$ & - & 1 \\
\hline 21 & - & 5 & - & 1 & 05:58 & - & 0 \\
\hline 22 & 3 & 0 & 17 & 2 & 05:58 & 84 & 2 \\
\hline 23 & 77 & 8 & 81 & 3 & $06: 06$ & 43 & 0 \\
\hline 24 & 79 & 8 & 27 & 2 & $06: 14$ & 85 & 2 \\
\hline 25 & 41 & 2 & 43 & 2 & $06: 16$ & 1 & 0 \\
\hline 26 & 95 & 20 & 53 & 3 & $06: 36$ & 22 & 0 \\
\hline 27 & 21 & 1 & 95 & 7 & $06: 37$ & 30 & 0 \\
\hline 28 & 0 & 0 & 25 & 2 & $06: 37$ & 12 & 0 \\
\hline 29 & 73 & 8 & 97 & 7 & $06: 45$ & 71 & 1 \\
\hline 30 & 42 & 2 & 68 & 3 & $06: 47$ & 99 & 5 \\
\hline 31 & 19 & 1 & 49 & 2 & $06: 48$ & 7 & 0 \\
\hline 32 & 30 & 2 & 54 & 3 & $06: 50$ & 83 & 2 \\
\hline 33 & 22 & 1 & 48 & 2 & $06: 51$ & 85 & 2 \\
\hline 34 & 17 & 1 & 16 & 2 & $06: 52$ & 9 & 0 \\
\hline 35 & 31 & 2 & 84 & 3 & $06: 54$ & 66 & 1 \\
\hline 36 & 63 & 7 & 65 & 3 & 07:01 & 41 & 0 \\
\hline 37 & 9 & 0 & 49 & 2 & 07:01 & 26 & 0 \\
\hline 38 & 73 & 8 & 64 & 3 & 07:09 & 18 & 0 \\
\hline 39 & 23 & 1 & 43 & 2 & $07: 10$ & 37 & 0 \\
\hline 40 & 2 & 0 & 29 & 2 & $07: 10$ & 14 & 0 \\
\hline 41 & 57 & 6 & 96 & 7 & $07: 16$ & 53 & 0 \\
\hline 42 & 36 & 2 & 23 & 2 & $07: 18$ & 42 & 0 \\
\hline 43 & 9 & 0 & 43 & 2 & $07: 18$ & 20 & 0 \\
\hline 44 & 0 & 0 & 24 & 2 & $07: 18$ & 49 & 0 \\
\hline 45 & 78 & 8 & 20 & 2 & $07: 26$ & 24 & 0 \\
\hline 46 & 2 & 0 & 37 & 2 & $07: 26$ & 98 & 5 \\
\hline 47 & 35 & 2 & 19 & 2 & $07: 28$ & 69 & 1 \\
\hline 48 & 79 & 8 & 29 & 2 & $07: 36$ & 69 & 1 \\
\hline 49 & 58 & 6 & 27 & 2 & $07: 42$ & 11 & 0 \\
\hline 50 & 4 & 0 & 22 & 2 & $07: 42$ & 23 & 0 \\
\hline
\end{tabular}

Computation of Operating Characteristics of queue two:

- $\quad$ Mean inter-arrival time $=\frac{\text { Total inter-arrival time }}{\text { Total no.of arrivals }}=\frac{219}{50}$

$=4.38$ minutes per customer 
- $\quad$ Arrival rate, $\lambda_{2}=\frac{1}{\text { Mean inter-arrival time }}=\frac{1}{4.38}$ $=0.228$ customers per minute

- $\quad$ Mean service time $=\frac{\text { Total service time }}{\text { No.of customers served }}=\frac{136}{50}$

$=\mathbf{2 . 7 2}$ minutes per customer

- $\quad$ Service rate $\mu_{2}=\frac{1}{\text { Mean Service time }}=\frac{1}{2.72}$ $=0.368$ customers per minute

- Mean waiting time of customers in queue $=\frac{\text { Sum of customers waiting time }}{\text { Total no.of arrivals }}=\frac{41}{50}$ $=0.82$ minutes per customer

- Mean time a customer spends in the system (checkout counter)

$=$ Average service time + Average waiting time in queue $=2.72+0.82=\mathbf{3 . 5 4}$ minutes

- $\quad$ Service facility Utilization at server two $=\frac{\lambda}{\mu}=\mathbf{0 . 6 2 0}$

Computation of the average of the Operating Characteristics of the queuing system represented at the checkout point with both servers:

- $\quad$ Mean inter-arrival time $=\frac{4.7+4.38}{2}=4.54$ minutes $/$ customer

- Mean Arrival rate $\lambda=\frac{1}{4.54}=\mathbf{0 . 2 2}$ customers $/$ minute

- Mean service time $=\frac{4.38+2.72}{2}=\mathbf{3 . 5 5}$ minutes $/$ customer

- $\quad$ Mean Service rate $\mu=\frac{1}{3.55}=\mathbf{0 . 2 8 2}$ customers/ minute

- Mean Waiting time in Queue $=\frac{3.06+0.82}{2}=\mathbf{1 . 9 4}$ minutes/ customer

- Mean Waiting time in System(Queue and in service) $=\frac{7.44+3.54}{2}=\mathbf{5 . 4 9}$ minutes $/$ customer

- Total Service facility Utilization $=\frac{\lambda}{\mathrm{c} \mu}=\frac{0.22}{2 * 0.282}=\mathbf{0 . 3 9}$

\section{Discussions and Conclusions:-}

Majority of the respondents visit the store at least once a week. Consumers mainly purchase grocery and staples, followed by cosmetics, fruits and vegetables, and dairy products from this Supermarket. Among the various factors that affect customer purchase behaviour at the store, the predominant ones are convenience and ease of access, variety of product categories, quality and availability of products. Chi square test reveals that the significant factor affecting purchase behaviour at this Supermarket is 'convenience and ease of access.' The association tests of purchase behaviour and few other attributes such as availability of variety of brands and store ambience have given insignificant results. This may be due to the fact that the study is done at a brick and mortar Supermarket outlet. Considering that customers are increasingly switching to the e-grocery mode of shopping, their purchase behaviour at a brick and mortar store is mainly driven by the 'convenience and ease of access factor.' Among the various loyalty programs of the store, majority of the shoppers prefer redemption of loyalty points at the time of purchase and use of off-price discounts, compared to availing bonus packs or coupons. It is also seen that age is a significant factor with respect to the impact of loyalty programs. Therefore the store could contemplate on designing loyalty programs that are age-group specific which could probably enhance footfalls at the store and bring about customer retention. This could also be one of the effective marketing strategies that could be adopted by Supermarkets in the brick and mortar space to retain those customers who visit them due to ease of access.

This study develops a queuing model for multiple servers with parallel queues at the sales checkout point. Monte Carlo simulation technique is performed and the operating characteristics have been computed to understand the performance of queuing system at the checkout point and associate it with the dimension of customer satisfaction. It is clearly seen that the average arrival rate is less than the average service rate. So the system is stable and the queue does not generate infinitely. It is seen that the service time at the first server is higher than that of the second server, hence the waiting time of customers at queue one is higher than that of the second server. The average time customers wait in the queue is about 2 minutes. The mean waiting time of customers in the system i.e. at queue and in service, is about 5.5 minutes, reflecting higher customer satisfaction at the checkout counters. The utilization at server one is $93.4 \%$ which indicates that it is busy most of the time. The reason may be attributed to the increased 
service time at server one. Server two appears to be more efficient with better service rate. Utilization at server two is $62 \%$ which implies that this server remains idle for longer periods of time. The net utilization at the checkout point i.e. the percentage of the time the checkout points are busy is $39 \%$ which means that on a typical weekday, at periods in the evening, there is no requirement for two servers at the checkout point. This analysis suggests that the cost associated with one of the servers could be reduced. It is recommended to the Management that the store could work efficiently at the checkout with one server only during the weekdays. This research therefore provides better insights to understand the overall shopper's behaviour, loyalty and satisfaction derived through analysis of waiting lines at the checkout counters in supermarkets.

\section{Acknowledgement:-}

The authors would like to acknowledge the Management of the Supermarket store in Bengaluru for permitting collection of observation data and data from customers visiting the Supermarket through a questionnaire technique. The authors would like to thank all the respondents who participated in the survey.

\section{References:-}

1. Afande, F. O., \& John, K. 2015. Factors affecting customer loyalty of supermarkets in Nyeri town, Kenya. Journal of Marketing and Consumer Research, 11. www.iiste.org.

2. Albright, S. C., \& Winston, W. L. Reprint 2014. Management science modelling. $4^{\text {th }}$ ed. Cengage Learning.

3. Applebaum, W. 1951. Studying customer behaviour in retail stores. Journal of Marketing, 16(2): 172-178.

4. Chawla, D. \& Sondhi, N. Reprint 2014. Research methodology concepts and cases. Vikas Publishing House Pvt. Ltd.

5. Chinwuko, E. C. E., Daniel, E. C., Ugochukwu, O. P., \& Obiora, O. J. 2014. Analysis of a queuing system in an organization (a case study of First Bank PLC, Nigeria). American Journal of Engineering Research, 3(2): 6372.

6. Gross, D., Shortle, J. F., Thompson, J. M., \& Harris, C. M. Reprint: 2014. Fundamentals of queueing theory. Sahibabad, UP: Wiley India Pvt. Ltd.

7. Igwe, A., Onwumere, J. U. J., \& Egbo, O. P. 2014. Efficient queue management in supermarkets: A case study of Makurdi Town, Nigeria. European Journal of Business and Management, 6(39): 185-192.

8. Karolefski, J., Top Trends in Grocery Shopping for 2017 Announced. December 2016. http://www.prnewswire.com/news-releases/top-trends-in-grocery-shopping-for-2017-announced300379626.html.

9. Kotler, P. \& Keller, K. L. 2006. Marketing management. $12^{\text {th }}$ ed. Pearson Prentice Hall.

10. Neupane, R. 2015. The effects of brand image on customer satisfaction and loyalty intention in retail supermarket chain UK. International Journal of Social Sciences and Management, 2(1): 9-26.

11. Priyangika, J. S. K. C., \& Cooray, T. M. J. A. 2016. Analysis of the sales checkout operation in supermarket using queuing theory. Universal Journal of Management, 4(7): 393-396.

12. Rana, S. S., Osman, A., \& Othman, Y. H. 2015. Factors affecting purchase intention of customers to shop at hypermarkets. Mediterranean Journal of Social Sciences, 6(3): 429-434.

13. Sangvikar, B. V., \& Katole, H. J. 2012. A study of consumer purchase behaviour in organized retail outlets. Journal of Business and Retail Management Research (JBRMR), 7(1): 39-47.

14. Shanmugasundaram, S., \& Punitha, S. 2014. A study on multi server queuing simulation. International Journal of Science and Research, 3(7).

15. Wang, W. C., Chen, Y. C., \& Chu, Y. C. 2009. A study of customer loyalty management in Chinese retail supermarket. International Journal of Business and Management, 4(11): 85-95.

16. Zakaria, I., Rahman, B. A., Othman, A. K., Yunus, N. A. M., Dzulkipli, M. R., \& Osman, M. A. F. 2014. The relationship between loyalty program, customer satisfaction and customer loyalty in retail industry: A case study. Procedia-Social and Behavioural Sciences, 129: 23-30.

17. Zikmund, W. 2000. Business research methods. $6^{\text {th }}$ ed. Harcourt College Publishers. 